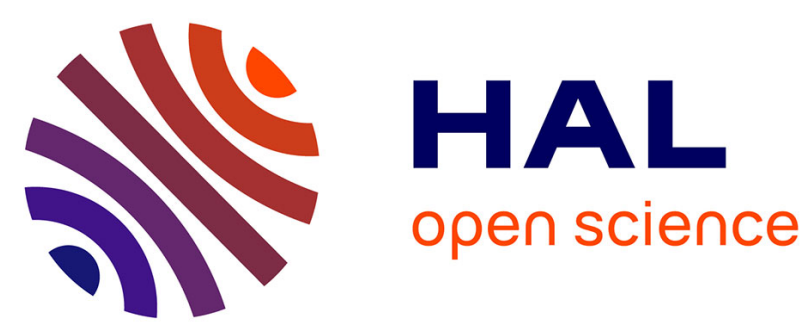

\title{
Unusual association of amyotrophic lateral sclerosis and myasthenia gravis: a dysregulation of the adaptive immune system?
}

Maria del Mar Amador, Nadia Vandenberghe, Nawel Berhoune, Jean-Philippe Camdessanché, Sophie Gronier, Emilien Delmont, Claude Desnuelle, Pascal Cintas, Sophie Pittion, Sarah Louis, et al.

\section{To cite this version:}

Maria del Mar Amador, Nadia Vandenberghe, Nawel Berhoune, Jean-Philippe Camdessanché, Sophie Gronier, et al.. Unusual association of amyotrophic lateral sclerosis and myasthenia gravis: a dysregulation of the adaptive immune system?. Neuromuscular Disorders, 2016, 10.1016/j.nmd.2016.03.004 . hal-01302532

\section{HAL Id: hal-01302532 \\ https://hal.sorbonne-universite.fr/hal-01302532}

Submitted on 14 Apr 2016

HAL is a multi-disciplinary open access archive for the deposit and dissemination of scientific research documents, whether they are published or not. The documents may come from teaching and research institutions in France or abroad, or from public or private research centers.
L'archive ouverte pluridisciplinaire HAL, est destinée au dépôt et à la diffusion de documents scientifiques de niveau recherche, publiés ou non, émanant des établissements d'enseignement et de recherche français ou étrangers, des laboratoires publics ou privés. 


\section{Unusual association of amyotrophic lateral sclerosis and myasthenia gravis: a dysregulation of the adaptive immune system ?}

Maria del Mar Amador ${ }^{\mathrm{a}}$ MD, Nadia Vandenberghe ${ }^{\mathrm{b}}$ MD, Nawel Berhoune ${ }^{\mathrm{b}}$, MD, JeanPhilippe Camdessanché ${ }^{\mathrm{c}} \mathrm{MD}, \mathrm{PhD}$, Sophie Gronier ${ }^{\mathrm{d}} \mathrm{MD}$, Emilien Delmont ${ }^{\mathrm{d}} \mathrm{MD}, \mathrm{PhD}$, Claude Desnuelle ${ }^{\mathrm{d}}$ MD, PhD, Pascal Cintas $^{\mathrm{e}}$ MD, Sophie Pittion ${ }^{\mathrm{f}}$ MD, Sarah Louis ${ }^{\mathrm{g}}$ MD, Sophie Demeret ${ }^{\mathrm{h}}$ MD, Timothée Lenglet ${ }^{\mathrm{a}} \mathrm{MD}$, Vincent Meininger ${ }^{\mathrm{a}} \mathrm{MD}$, PhD, François Salachas $^{\mathrm{a}} \mathrm{MD}$, Pierre-François Pradat ${ }^{\mathrm{a}, \mathrm{i}} \mathrm{MD}, \mathrm{PhD}$, Gaëlle Bruneteau ${ }^{\mathrm{a}, \mathrm{j}} \mathrm{MD}, \mathrm{PhD}$.

aAPHP, Hôpital Pitié-Salpêtrière, Département des Maladies du Système Nerveux, Centre référent SLA, Paris, France;

${ }^{\mathrm{b}}$ Service d'Electroneuromyographie et Service de Neurologie C, Centre Sclérose Latérale Amyotrophique de Lyon, Hôpital Neurologique Pierre Wertheimer, Hospices Civils de Lyon, Lyon, France.

${ }^{c}$ CHU de Saint-Étienne, hôpital Nord, service de neurologie, Saint-Étienne, France; CHU de Saint-Étienne, centre SLA et maladies du motoneurone, France.

${ }^{\mathrm{d}}$ Centre de référence maladies neuromusculaires et SLA, pôle neurosciences cliniques, hôpital l'Archet, CHU de Nice, France

${ }^{\text {e }}$ Centre SLA, Unité de neurophysiologie clinique, CHU Toulouse Purpan, France

${ }^{\mathrm{f}}$ Centre SLA, Service de Neurologie, Hôpital Central, Nancy, France;

${ }^{\mathrm{g}}$ Service de Neurologie, Hôpital Central, Nancy, France

${ }^{\text {h }}$ APHP, Hôpital Pitié-Salpêtrière, Unité de Réanimation Neurologique, Neurologie 1, Paris, France

${ }^{\text {i }}$ Sorbonne Universités, UPMC Univ Paris 06, CNRS, INSERM, Laboratoire d'Imagerie Biomédicale, F-75013, Paris, France 
${ }^{\mathrm{j}}$ Inserm U 1127, CNRS UMR 7225, Sorbonne Universités, UPMC Univ Paris 06 UMR S

1127, Institut du Cerveau et de la Moelle épinière, ICM, F-75013, Paris, France

\title{
Correspondence:
}

Dr Gaëlle Bruneteau, Centre Référent SLA, Hôpital Pitié-Salpêtrière, 47-83 Bd de l'Hôpital, 75013 Paris, France

Phone: +33 142 162471; Fax: +33 142162473

E-mail: gaelle.bruneteau@psl.aphp.fr

\section{Highlights}

- We describe the largest series of co-occurence of ALS and myasthenia gravis.

- This association is rare and requires strict diagnostic criteria.

- It may be triggered by a dysfunction of the adaptive immune system in both disorders.

- False positivity for anti-AChR antibodies is encountered in some ALS patients.

- Transient response to acetylcholinesterase inhibitors is also possible in ALS.

\begin{abstract}
Myasthenia gravis is an autoimmune disorder affecting neuromuscular junctions that has been associated with a small increased risk of amyotrophic lateral sclerosis (ALS). Here, we describe a retrospective series of seven cases with a concomitant diagnosis of ALS and myasthenia gravis, collected among the 18 French reference centers for ALS in a twelve years period. After careful review, only six patients strictly met the diagnostic criteria for both ALS and myasthenia gravis. In these patients, limb onset of ALS was reported in five (83\%) cases. Localization of myasthenia gravis initial symptoms was ocular in three (50\%) cases, generalized in two (33\%) and bulbar in one (17\%). Median delay between onset of the two
\end{abstract}


conditions was 19 months (6-319 months). Anti-acetylcholine receptor antibodies testing was positive in all cases. All patients were treated with riluzole and one had an associated immune-mediated disease. In the one last ALS case, the final diagnosis was false-positivity for anti-acetylcholine receptor antibodies. The co-occurrence of ALS and myasthenia gravis is rare and requires strict diagnostic criteria. Its demonstration needs thoughtful interpretation of electrophysiological results and exclusion of false positivity for myasthenia gravis antibody testing in some ALS cases. This association may be triggered by a dysfunction of adaptive immunity.

\section{Keywords}

Amyotrophic lateral sclerosis, myasthenia gravis, immunology, neuromuscular transmission

\section{Introduction}

Amyotrophic lateral sclerosis (ALS) is a rapidly progressive neurodegenerative disorder involving motor neurons. To date, there are no specific tests or biological markers to confirm the diagnosis [1], which remains based on clinical and electrophysiological findings together with exclusion of potentially treatable conditions presenting with similar symptoms, such as myasthenia gravis (MG). This rare autoimmune neuromuscular disorder is characterized by a defective transmission of nerve impulses to muscles. Here, we report seven patients from the French cohort of ALS patients with a concomitant diagnosis of ALS and MG. In the light of the current literature on this unusual association, we discuss diagnostic difficulties and pathophysiological mechanisms.

\section{Patients and Methods}


We conducted a retrospective review of cases referred with a concomitant diagnosis of ALS and MG, between 2002 and 2014, to one of the 18 French reference centers for ALS. These departments are specialist tertiary referral centers for motor neuron diseases and utilize standardized diagnostic pathways according to French [2] and European guidelines [3]. Patients with atypical motor neuron disorders, including those with concomitant other neurological diseases, are systematically recorded. The French cohort comprised 4757 patients in 2014. The neurologists of these centers were asked to identify all patients with an associated diagnosis of ALS and MG. For all patients with a recorded diagnosis of concomitant ALS and MG, detailed information on the neurological signs and symptoms, laboratory results and electrophysiological data were collected from review of the clinical charts. Each case was then classified according to the revised El Escorial World Federation of Neurology criteria for the diagnosis of ALS, which requires evidence of upper and lower motor neuron degeneration and spreading of signs and symptoms to different anatomic regions (brainstem, cervical, thoracic and lumbosacral spinal cord) [4]. The diagnosis of MG was made based on clinical and paraclinical findings [5]. Suggestive clinical features were weakness with exacerbation by exercise and variability of symptoms, as well as improvement after cholinesterase inhibitor treatment (neostigmine or edrophonium test). Laboratory tests supporting the diagnosis of MG were the detection of specific autoantibodies and a significant decrement (> 10\%) evidenced by RNS tests. This study was approved by the local ethics committee according to the French regulations.

\section{Results}

\subsection{Patients' characteristics}


Seven patients with a concomitant diagnosis of ALS and MG were included in the study. Patients' characteristics are summarized in Table 1 (detailed case reports are available as Supplementary material). After careful review of clinical records, six patients (four males, two females, median age 56) met the diagnosis criteria for both ALS and MG (Table 2). Median delay between onset of the two conditions was 19 months (6-319 months). Limb onset of ALS symptoms was reported in $83 \%$ of the patients. Localization of MG initial symptoms was ocular in 50\% cases, generalized in $33 \%$ and bulbar in $17 \%$.

\subsection{Patients with ALS as inaugural disease}

In three cases (patient 2, 6 and 7), ALS diagnosis was established before the occurrence of MG first symptoms. In this subgroup of patients, median age at onset was 39 (range 34-89). ALS symptoms began in the bulbar region in one case and in the lumbar region in two. Median delay between ALS onset and occurrence of first MG symptoms was 27 months (range 6-71). Concomitant diagnosis of MG was suspected based upon the occurrence of ocular symptoms (fluctuating ptosis or diplopia) in two cases; ocular symptoms and dramatic worsening of swallowing difficulties with marked diurnal variations, in one case. All three patients had positive testing for AChR-ab and significant decrement after RNS.

\subsection{Patients with MG as inaugural disease}

In three cases (patients 1, 3 and 5) MG diagnosis preceded ALS diagnosis. Median age at MG diagnosis was 72 (range 40-77). All patients had a positive testing for AChR-ab and a positive response to acetylcholinesterase inhibitor. In two cases a significant decrement was observed after RNS in at least one muscle. Median delay between MG initial symptoms and ALS onset was 11 months (range 8-319). The diagnosis of concomitant ALS was based upon the 
occurrence of a progressive limb weakness with pyramidal signs, and a diffuse neurogenic pattern on needle electromyography study.

\subsection{Biological false positivity for AChR-ab}

One case (patient 4) was retrospectively classified as a biological false positive for AChR-ab. In this patient, AChR-ab were detected during the diagnostic work-up of typical bulbar-onset ALS. Cholinesterase inhibitor therapy started in association with riluzole induced no improvement in motor symptoms, and the patient died shortly after treatment initiation.

\section{Discussion}

Here, we report the largest series to date of patients with a concomitant diagnosis of ALS and MG. After careful review, six patients met the diagnostic criteria for both disorders. In three, ALS first symptoms occurred several months or years after the diagnosis of MG. In that situation, the main problem lies in not mistakenly attribute worsening of the patient's condition to MG. Marked muscle atrophy may occasionally be present in MG [6,7] and fasciculation can be seen as a side effect of cholinesterase inhibitor therapy. Conversely, the presence of pyramidal signs should attract attention and the diagnosis of concomitant ALS should be considered if EMG evaluation shows acute and chronic denervation outside of motor deficit territories. In three other patients, the diagnosis of MG was made several years after ALS onset, with attention being drawn by marked diurnal variations and ocular symptoms, unusual in the context of motor neuron disorder. Two of them were young-onset ALS-patients $(<45)$, with relatively slow disease progression. It is to note that, in one patient (No. 6), MG symptoms were mild and disappeared spontaneously after several months, without specific treatment. Albeit rare, prolonged (more than a few years) remissions can be 
seen without treatment in MG patients [8], and unusually long spontaneous remission, as observed in our patient, has been described in ocular myasthenia [9].

Retrospectively, we only identified six cases with co-occurrence of ALS and MG during a twelve years period. Even if we cannot exclude that some cases may not have been referred to one of the French reference centers for ALS, this association seems rare, as supported by the small number of similar cases reported in the literature [10-12]. The combination of these two rare diseases may be a by chance association. However, it has recently been suggested that several preexisting autoimmune diseases, including MG, were associated with a small increased risk of ALS [13]. There are evidences of systemic immune alterations in ALS patients, with immunologic activation in blood cells linked with ALS disease state and rate of progression $[14,15]$. Several studies also showed that immunoglobulins from ALS patients can affect NMJ functional characteristics [16-18]. Furthermore, a proportion of ALS patients have serum antibodies directed against various targets, including the membrane protein LRP4 [19], an autoantigen implicated in some MG cases [20-22]. The role of riluzole in the development of MG in subjects suffering from ALS has also been discussed [12], as "myasthenia" has been reported as a possible adverse event during riluzole treatment in controlled ALS trials (http://www.accessdata.fda.gov). The effect of riluzole on the function of muscle AChR has been investigated in vitro using electrophysiological techniques. Riluzole induced AChR block, with a faster and stronger block for AChR foetal isoform containing a $\gamma$-subunit, which is re-expressed along the entire muscle fiber after denervation. However, the adult AChR isoform was blocked by riluzole only with acetylcholine applications far outlasting the typical duration of synaptic events. Furthermore, in the same study, treatment of ALS patients with riluzole did not impair nerve-muscle transmission explored by RNS tests [23]. 
Finally, in one case retrospectively classified as biological "false positive", significant serum titer of AChR-ab $(2.4 \mathrm{nmol} / \mathrm{l}, \mathrm{N}<0.5)$ was detected during ALS diagnostic work-up, in the absence of clinical signs suggestive of MG. Although AChR-ab are considered as highly specific for the diagnosis of MG, biological false positivity has been rarely reported in patients with motor neuron disorders [24-29]. In some patients who had received snake venom as a therapy, cross-reacting antibodies were responsible for technical false positivity $[26,27]$. In the absence of snake venom therapy (as in our case), the frequency of AChR-ab positivity in MND patients was evaluated about 5\% [25,26]. In some patients, AChR-ab titers may fluctuate during the progression of ALS $[26,28]$. The mechanism by which AChR-ab are produced in some ALS cases is unknown. It may be related to the morphological alterations of neuromuscular junctions that are present from early disease stage [30,31] and associated with clinically detectable impairment of neuromuscular transmission in up to $53 \%$ of ALS patients [32,33]. Positive cholinesterase inhibitor test has also been reported in ALS cases [34]. In the context of ALS, the diagnosis of concomitant MG should thus be discussed only in the presence of suggestive clinical features (i.e. ocular symptoms and marked variability of symptoms).

In conclusion, the co-occurrence of ALS and MG is rare and requires strict diagnostic criteria. In particular, the clinician should be aware that serum antibodies directed against autoantigens implicated in MG may also be found in some ALS cases. Morphological changes of neuromuscular junctions are also present in ALS which may be responsible for significant impairment of neuromuscular transmission and transient response to acetylcholinesterase inhibitors in some patients. The unusual association of these two diseases may be driven by dysregulation of the adaptive immune system in both conditions. 


\section{Appendix: Supplementary material}

\section{References}

[1] Chio A, Traynor BJ. Motor neuron disease in 2014. Biomarkers for ALS--in search of the Promised Land. Nat Rev Neurol 2015;11:72-4.

[2] Vandenberghe N. [Ancillary exams in the diagnosis of amyotrophic lateral sclerosis]. Rev Neurol (Paris) 2006;162 Spec No 2:4S57-66.

[3] Andersen PM, Abrahams S, Borasio GD et al. EFNS guidelines on the clinical management of amyotrophic lateral sclerosis (MALS)--revised report of an EFNS task force. Eur J Neurol 2012;19:360-75.

[4] Brooks BR, Miller RG, Swash M, Munsat TL. El Escorial revisited: revised criteria for the diagnosis of amyotrophic lateral sclerosis. Amyotroph Lateral Scler Other Motor Neuron Disord 2000;1:293-9.

[5] Berrih-Aknin S, Frenkian-Cuvelier M, Eymard B. Diagnostic and clinical classification of autoimmune myasthenia gravis. J Autoimmun 2014;48-49:143-8.

[6] Brownell B, Oppenheimer DR, Spalding JM. Neurogenic muscle atrophy in myasthenia gravis. J Neurol Neurosurg Psychiatry 1972;35:311-22.

[7] Samuraki M, Furui E, Komai K, Takamori M, Yamada M. Myasthenia gravis presenting with unusual neurogenic muscle atrophy. Muscle Nerve 2007;36:394-9.

[8] Oosterhuis HJ. The natural course of myasthenia gravis: a long term follow up study. J Neurol Neurosurg Psychiatry 1989;52:1121-7. 
[9] Al-Hashel J, Rashad HM, Rousseff RT. An adult patient with ocular myasthenia and unusually long spontaneous remission. Case Rep Neurol Med 2014;2014:372769.

[10] Naik KR, Saroja AO, Mahajan M. Unusual occurrence of amyotrophic lateral sclerosis in myasthenia gravis. Amyotroph Lateral Scler 2012;13:477-8.

[11] Pinto S, de Carvalho M. Amyotrophic lateral sclerosis patients and ocular ptosis. Clin Neurol Neurosurg 2008;110:168-70.

[12] Restivo DA, Bianconi C, Ravenni R, De Grandis D. ALS and myasthenia: An unusual association in a patient treated with riluzole. Muscle Nerve 2000;23:294-5.

[13] Turner MR, Goldacre R, Ramagopalan S, Talbot K, Goldacre MJ. Autoimmune disease preceding amyotrophic lateral sclerosis: an epidemiologic study. Neurology $2013 ; 81: 1222-5$.

[14] Zhang R, Gascon R, Miller RG et al. Evidence for systemic immune system alterations in sporadic amyotrophic lateral sclerosis (sALS). J Neuroimmunol 2005;159:215-24.

[15] Henkel JS, Beers DR, Wen S et al. Regulatory T-lymphocytes mediate amyotrophic lateral sclerosis progression and survival. EMBO Mol Med 2013;5:64-79.

[16] Appel SH, Engelhardt JI, Garcia J, Stefani E. Immunoglobulins from animal models of motor neuron disease and from human amyotrophic lateral sclerosis patients passively transfer physiological abnormalities to the neuromuscular junction. Proc Natl Acad Sci U S A 1991;88:647-51. 
[17] O'Shaughnessy TJ, Yan H, Kim J et al. Amyotrophic lateral sclerosis: serum factors enhance spontaneous and evoked transmitter release at the neuromuscular junction. Muscle Nerve 1998;21:81-90.

[18] Uchitel OD, Appel SH, Crawford F, Sczcupak L. Immunoglobulins from amyotrophic lateral sclerosis patients enhance spontaneous transmitter release from motor-nerve terminals. Proc Natl Acad Sci U S A 1988;85:7371-4.

[19] Tzartos JS, Zisimopoulou P, Rentzos M et al. LRP4 antibodies in serum and CSF from amyotrophic lateral sclerosis patients. Ann Clin Transl Neurol 2014;1:80-7.

[20] Higuchi O, Hamuro J, Motomura M, Yamanashi Y. Autoantibodies to low-density lipoprotein receptor-related protein 4 in myasthenia gravis. Ann Neurol 2011;69:41822.

[21] Zhang B, Tzartos JS, Belimezi M et al. Autoantibodies to lipoprotein-related protein 4 in patients with double-seronegative myasthenia gravis. Arch Neurol 2012;69:445-51.

[22] Pevzner A, Schoser B, Peters K et al. Anti-LRP4 autoantibodies in AChR- and MuSKantibody-negative myasthenia gravis. J Neurol 2012;259:427-35.

[23] Deflorio C, Palma E, Conti L et al. Riluzole blocks human muscle acetylcholine receptors. J Physiol 2012;590:2519-28.

[24] Abbott RJ, Holden D, Currie S. False positive anti-acetylcholine receptor antibodies in motorneurone disease. Lancet 1986;1:906-7.

[25] Appel SH, Stockton-Appel V, Stewart SS, Kerman RH. Amyotrophic lateral sclerosis. Associated clinical disorders and immunological evaluations. Arch Neurol $1986 ; 43: 234-8$. 
[26] Ashizawa T. False positive anti-acetylcholine receptor antibodies in motorneurone disease. Lancet 1986;1:1272.

[27] Mittag TW, Caroscio J. False-positive immunoassay for acetylcholine-receptor antibody in amyotrophic lateral sclerosis. N Engl J Med 1980;302:868.

[28] Okuyama Y, Mizuno T, Inoue H, Kimoto K. Amyotrophic lateral sclerosis with antiacetylcholine receptor antibody. Intern Med 1997;36:312-5.

[29] Mehanna R, Patton EL, Jr., Phan CL, Harati Y. Amyotrophic lateral sclerosis with positive anti-acetylcholine receptor antibodies. Case report and review of the literature. J Clin Neuromuscul Dis 2012;14:82-5.

[30] Vinsant S, Mansfield C, Jimenez-Moreno R et al. Characterization of early pathogenesis in the SOD1(G93A) mouse model of ALS: part II, results and discussion. Brain Behav 2013;3:431-57.

[31] Bruneteau G, Bauche S, Gonzalez de Aguilar JL et al. Endplate denervation correlates with Nogo-A muscle expression in amyotrophic lateral sclerosis patients. Annals of Clinical and Translational Neurology doi: 10 1002/acn3 1792015.

[32] Killian JM, Wilfong AA, Burnett L, Appel SH, Boland D. Decremental motor responses to repetitive nerve stimulation in ALS. Muscle Nerve 1994;17:747-54.

[33] Wang FC, De Pasqua V, Gerard P, Delwaide PJ. Prognostic value of decremental responses to repetitive nerve stimulation in ALS patients. Neurology 2001;57:897-9.

[34] Mulder DW, Lambert EH, Eaton LM. Myasthenic syndrome in patients with amyotrophic lateral sclerosis. Neurology 1959;9:627-31. 
Table 1: Clinical characteristics of patients recorded in the database with a concomitant diagnosis of ALS and MG

\begin{tabular}{|c|c|c|c|c|c|c|c|}
\hline $\begin{array}{c}\text { Patient } \\
\text { No. }\end{array}$ & Gender & $\begin{array}{l}\text { Age at first } \\
\text { symptoms } \\
\text { (inaugural } \\
\text { condition) }\end{array}$ & $\begin{array}{l}\text { Inaugural } \\
\text { condition } \\
\text { recorded }\end{array}$ & $\begin{array}{c}\text { Associated } \\
\text { immune- } \\
\text { mediated } \\
\text { disease }\end{array}$ & $\begin{array}{c}\text { Delay } \\
\text { between onset } \\
\text { of conditions } \\
\text { (months) }\end{array}$ & $\begin{array}{c}\text { Site of onset } \\
\text { of ALS } \\
\text { symptoms }\end{array}$ & $\begin{array}{c}\text { Regions with } \\
\text { EMG } \\
\text { neurogenic } \\
\text { pattern } \\
\end{array}$ \\
\hline 1 & $\mathrm{~F}$ & 72 & MG & No & 11 & UL proximal & UL/LL/bulbar \\
\hline 2 & M & 34 & ALS & No & 71 & UL distal & UL/LL/bulbar \\
\hline 3 & M & 40 & MG & No & 319 & UL proximal & UL/LL \\
\hline 4 & $\mathrm{~F}$ & 88 & $\mathrm{MG}+\mathrm{ALS}$ & No & 0 & Bulbar & UL/LL/bulbar \\
\hline 5 & M & 77 & MG & Basedow's & 8 & LL distal & UL/LL/bulbar \\
\hline 6 & $\mathrm{~F}$ & 39 & ALS & No & 27 & Bulbar & UL/LL \\
\hline 7 & M & 89 & ALS & No & 6 & LL distal & UL/LL \\
\hline
\end{tabular}

ALS: Amyotrophic Lateral Sclerosis, MG : Myasthenia gravis, EMG: needle electromyography, UL: upper limbs, LL: lower limbs, AChR-ab : antibodies against acetylcholine receptor, CMAP : compound motor action potential, IVIG: Intravenous immunoglobulin, RNS test: repetitive nerve stimulation test at slow stimulus rate (3-5Hz), AChE inhibitors: acetylcholinesterase inhibitors, ND: not done.

Table 1 (continued)

\begin{tabular}{|c|c|c|c|c|c|c|c|c|}
\hline $\begin{array}{c}\text { ALS } \\
\text { classification a }\end{array}$ & $\begin{array}{c}\text { MG initial } \\
\text { symptoms }\end{array}$ & $\begin{array}{c}\text { AChR-ab } \\
\text { level } \\
(\mathbf{n m o l} / \mathbf{l})\end{array}$ & $\begin{array}{c}\text { CMAP } \\
\text { decrement } \\
\text { at RNS } \\
\text { test } \\
(\boldsymbol{\%})\end{array}$ & $\begin{array}{c}\text { Response } \\
\text { to } \\
\text { AchE } \\
\text { inhibitors }\end{array}$ & $\begin{array}{c}\text { Immune- } \\
\text { directed } \\
\text { therapy }\end{array}$ & Riluzole $^{\mathbf{b}}$ & $\begin{array}{c}\text { Final } \\
\text { diagnosis } \\
\text { after } \\
\text { review }\end{array}$ \\
\hline & Probable & Ocular & 40 & $>10$ & Yes & $\begin{array}{c}\text { IVIG } \\
\text { plasmapheresis } \\
\text { azathioprin } \\
\text { mycophenolate } \\
\text { mofetil }\end{array}$ & Yes & $\begin{array}{c}\text { MG } \\
+ \\
\text { ALS }\end{array}$ \\
\hline
\end{tabular}




\begin{tabular}{|c|c|c|c|c|c|c|c|c|}
\hline $\mathbf{2}$ & Definite & Ocular & 5.9 & $>10$ & Yes & azathioprin & Yes & $\begin{array}{c}\text { MG } \\
+ \\
\text { ALS }\end{array}$ \\
\hline $\mathbf{3}$ & $\begin{array}{c}\text { Probable- } \\
\text { lab supported }\end{array}$ & Generalized & 8.4 & $>10$ & Yes & No & Yes & $\begin{array}{c}\text { MG } \\
+ \\
\text { ALS }\end{array}$ \\
\hline $\mathbf{4}$ & $\begin{array}{c}\text { Probable } \\
\mathbf{5}\end{array}$ & Bulbar & 2.4 & ND & No & No & Yes & $\begin{array}{c}\text { False } \\
\text { positive } \\
\text { for } \\
\text { AChR-ab }\end{array}$ \\
\hline & $\begin{array}{c}\text { lab supported } \\
\mathbf{6}\end{array}$ & Bulbar & $>8$ & ND & Yes & No & Yes & $\begin{array}{c}\text { MG } \\
+ \\
\text { ALS }\end{array}$ \\
\hline $\mathbf{7}$ & Probable & Ocular & 10 & $12-16$ & Yes & No & Yes & $\begin{array}{c}\text { ALS } \\
+ \\
\text { Ocular } \\
\text { Probable }\end{array}$ \\
\hline
\end{tabular}

${ }^{a}$ Each case was classified according to the revised El Escorial World Federation of Neurology criteria for the diagnosis of ALS [4].

${ }^{\mathrm{b}}$ None of the patients had undergone therapy with modified snake venom as an alternative treatment for ALS.

${ }^{c}$ The diagnosis of MG was made based on suggestive clinical features and paraclinical findings, including variable weakness, improvement after cholinesterase inhibitor treatment, detection of specific autoantibodies and significant decrement evidenced by RNS tests [5].

${ }^{\mathrm{d}}$ Positive edrophonium test. Spontaneous clinical remission of ocular MG symptoms after a few months, without any relapse over the follow-up period of 12 years.

Table 2: Characteristics of patients meeting the diagnostic criteria for both ALS and MG

\begin{tabular}{|c|c|c|c|}
\hline & $\begin{array}{c}\text { Total } \\
\mathbf{n = 6}\end{array}$ & $\begin{array}{c}\text { ALS as inaugural } \\
\text { condition } \\
\mathbf{n = 3}\end{array}$ & $\begin{array}{c}\text { MG as inaugural } \\
\text { condition } \\
\mathbf{n = 3}\end{array}$ \\
\hline Median age (range), years & $56(34-89)$ & $39(34-89)$. & $72(40-77)$ \\
\hline Gender, male/female & $4 / 2$ & $2 / 1$ & $2 / 1$ \\
\hline $\begin{array}{c}\text { Inaugural condition } \\
\text { ALS, } \mathbf{n}(\%)\end{array}$ & $3(50)$ & - & - \\
\hline
\end{tabular}




\begin{tabular}{|c|c|c|c|}
\hline MG, n (\%) & & & \\
\hline $\begin{array}{l}\text { Median delay between } \\
\text { symptom onset } \\
\text { of the } 2 \text { conditions } \\
\text { (range), months }\end{array}$ & $19(6-319)$ & $27(6-71)$ & $11(8-319)$ \\
\hline $\begin{array}{c}\text { ALS site of onset } \\
\text { Limb, n (\%) } \\
\text { Bulbar, n (\%) }\end{array}$ & $\begin{array}{l}5(83) \\
1(17)\end{array}$ & $\begin{array}{l}2(67) \\
1(33)\end{array}$ & $\begin{array}{c}3(100) \\
0(10)\end{array}$ \\
\hline $\begin{array}{l}\text { Localization of MG initia } \\
\text { symptoms }\end{array}$ & & & \\
\hline $\begin{array}{c}\text { Ocular, n (\%) } \\
\text { Bulbar, n (\%) } \\
\text { Generalized, n (\%) }\end{array}$ & $\begin{array}{l}3(50) \\
1(17) \\
2(33)\end{array}$ & $\begin{array}{c}0(0) \\
1(33)\end{array}$ & $\begin{array}{l}1(33) \\
1(33) \\
1(33)\end{array}$ \\
\hline
\end{tabular}

ALS: Amyotrophic Lateral Sclerosis, MG : Myasthenia Gravis 